University of Nebraska - Lincoln

DigitalCommons@University of Nebraska - Lincoln

Robert Katz Publications

Research Papers in Physics and Astronomy

November 1978

\title{
Radiobiological Aspects of Supralinear Photographic Emulsions
}

Robert Katz

University of Nebraska-Lincoln, rkatz2@unl.edu

Edward C. Pennington

University of Nebraska-Lincoln, edward-pennington@uiowa.edu

Follow this and additional works at: https://digitalcommons.unl.edu/physicskatz

Part of the Physics Commons

Katz, Robert and Pennington, Edward C., "Radiobiological Aspects of Supralinear Photographic Emulsions" (1978). Robert Katz Publications. 118.

https://digitalcommons.unl.edu/physicskatz/118

This Article is brought to you for free and open access by the Research Papers in Physics and Astronomy at DigitalCommons@University of Nebraska - Lincoln. It has been accepted for inclusion in Robert Katz Publications by an authorized administrator of DigitalCommons@University of Nebraska - Lincoln. 
Published in Physics in Medicine and Biology 23:6 (November 1978), pp. 1115-1123.

Copyright (C) 1978 The Institute of Physics. Used by permission.

http://www.iop.org/EJ/journal/PMB

Submitted December 16, 1977; revised April 3, 1978.

\title{
Radiobiological Aspects of Supralinear Photographic Emulsions
}

\author{
Robert Katz and E. C. Pennington \\ University of Nebraska-Lincoln, Lincoln, NE 68588, U.S.A.
}

\begin{abstract}
Nuclear emulsions of the Ilford $\mathrm{K}$ series, exposed to X-rays from 15 to $150 \mathrm{kV}_{\mathrm{p}}$ and systematically underdeveloped, exhibit supralinear blackness-exposure curves ranging from 1to 4 -hit in character, and whose shape is the same at all excitation voltages. Processing can be so adjusted that the curve shape is well represented by the model, and matches an experimental dose-response curve obtained with hamster cells after irradiation with gamma rays. The effective grain size of these emulsions is $1.3 \mu \mathrm{m}$ when normalized to unit density material for comparison with the radiation-sensitive elements of biological cells. With fractionated exposures, response curves which mimic Elkind recovery are produced.
\end{abstract}

\section{Introduction}

Photographic emulsions consist of dispersions of silver halide, principally silver bromide, crystals in gelatin. The crystals are often nearly spherical, and range in mean diameter from about 0.1 to $1.0 \mu \mathrm{m}$. The density of silver bromide is $6.5 \mathrm{~g}$ $\mathrm{cm}^{-3}$, so that when normalized to unit density, the effective grain size ranges from about 0.6 to $6 \mu \mathrm{m}$, encompassing the sizes often attributed to the radiosensitive elements of biological systems. For different emulsions and processing conditions, estimates of the energy required to make a grain developable with ionizing radiations vary from $500 \mathrm{eV}$ (Barkas 1963) to $1600 \mathrm{eV}$ (Erickson and Splettstosser 1977), while the corresponding values with visible light exposure are $30-300 \mathrm{eV}$. In passing diametrically through a grain $0.25 \mu \mathrm{m}$ in diameter even a minimum ionizing electron, near $1 \mathrm{MeV}$, loses $210 \mathrm{eV}$ on the average. It is not surprising that the response of most emulsions to ionizing radiations is linear at low dose, with no reciprocity law failure. In most cases emulsions can be described as 1-hit detectors (Valentine 1966) in their response to low-LET radiations of different quality. In their response to light, there is a low frequency threshold, required to raise an electron in the crystal from its valence to its conduction band, say $2.5 \mathrm{eV}$, and the response to incident light is supralinear, or many-hit, for many photons are required to produce an aggregation of neutral silver atoms in the crystal to constitute a latent image. The minimal number of silver atoms for a latent image, in the most sensitive emulsions, is 4 (Farnell and Chanter 1961, Mitchell 1978).

An exposed emulsion that has been developed so as to be a 1-hit detector is equally sensitive to absorbed dose, for a wide range of low-LET radiations. Its blackness is a saturating exponential function of the absorbed dose, of form 1 - 
$\mathrm{e}^{-x}$, the same for X-ray energies from 30 to $600 \mathrm{keV}$ effective energy (Greening 1951), and for electron beams from $10 \mathrm{keV}$ to $2 \mathrm{MeV}$ (Glocker 1960) for different films. For both X-rays and electrons, the initial radiosensitivity (at low dose) was found to be independent of the beam energy.

Some investigators have found slight initial supralinearity, up to a blackness which varies as the $5 / 4$ power of the exposure. The most extensive study of such emulsions was made by Dudley (1951). Several Kodak emulsions were exposed to electron beams, from $33 \mathrm{keV}$ to $1.19 \mathrm{MeV}$, with results shown in Figure 1. Here, the shape of the plot of net density against relative exposure was the same for all energies. For these emulsions, the mean grain diameter and its uncertainty $(2 \sigma)$ are No Screen $1.1 \pm 0.34 \mu \mathrm{m}$, Cine Positive $0.21 \pm 0.07 \mu \mathrm{m}$, Type A $0.17 \pm 0.03$ $\mu \mathrm{m}, \mathrm{NTB} 0.52 \pm 0.16 \mu \mathrm{m}$ (E. J. Hahn, private communication). In his discussion, Dudley noted that "The extent of the independence . . . of the blackness-exposure curve from electron energy ... is somewhat surprising. The curves for these films show that many of the grains are definitely not exposed in single hit events. One would therefore expect that at the lower energies, where specific ionization is higher, the curves would begin to approach single hit curves."

A contrary result was found by Golden and Tochilin (1959), who noted that there was a slight difference in shape of the blackness-exposure curves of three emulsions exposed to $\mathrm{X}$-rays and to gamma rays. With these emulsions, the response was linear to $30 \mathrm{kV}_{\mathrm{p}} \mathrm{X}$-rays and slightly supralinear to gamma and beta rays.

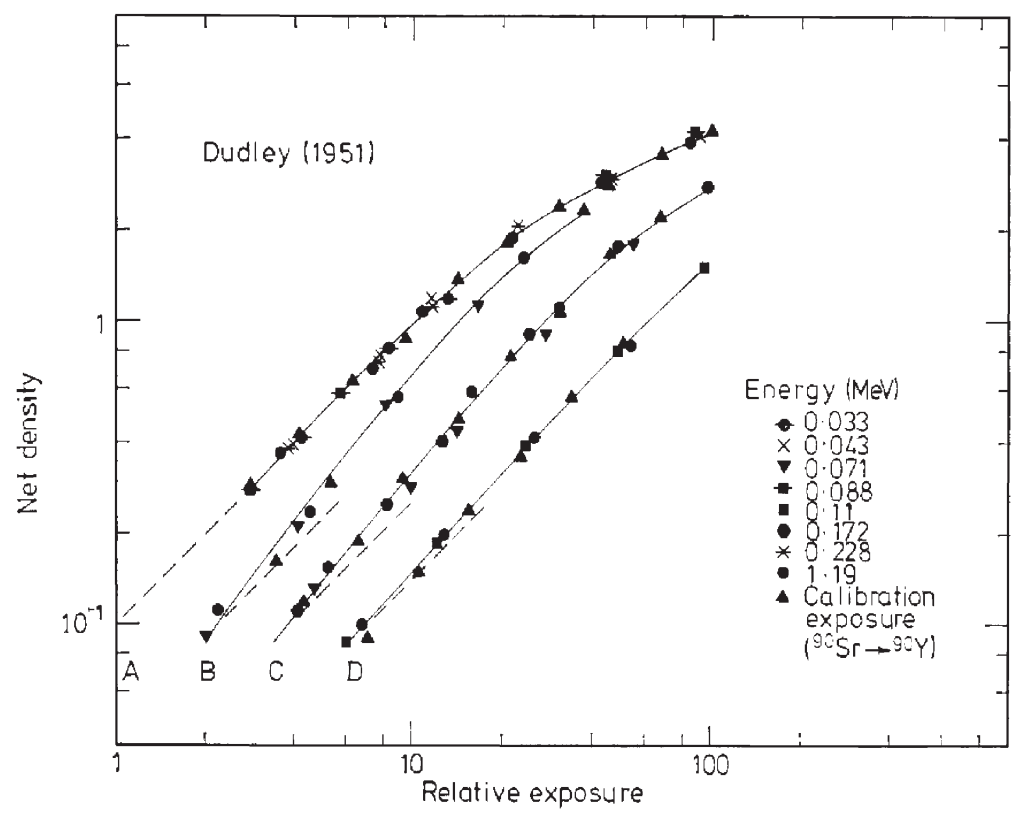

Figure 1. Blackness-exposure curves have the same shape for incident electron beams from $33 \mathrm{keV}$ to $1.19 \mathrm{MeV}$, for several emulsions, even when the curves are supralinear (Dudley 1951). Curves are: A = Eastman No Screen (single emulsion). B = Cine positive No. 5302. C = Eastman Type A (single emulsion). D = NTB stripping film. 


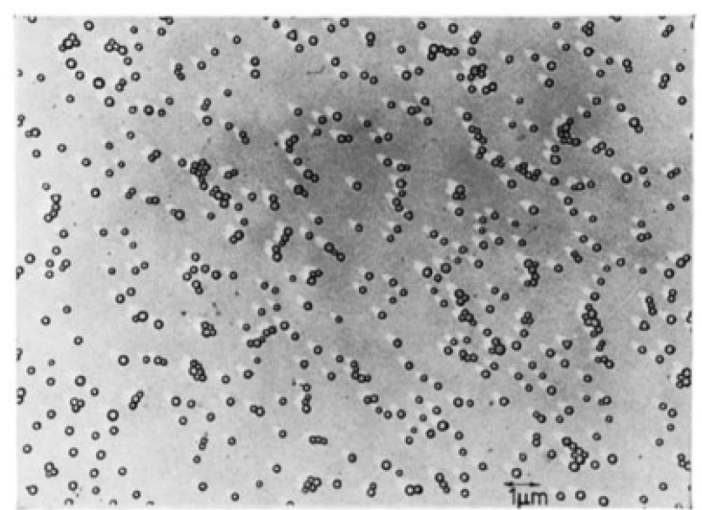

Figure 2. Electron micrograph of the grains of Ilford K.5 emulsion.

The question of the variation in shape of the blackness-exposure curve is a matter of some interest for the interpretation of the behavior of photographic emulsion, but more generally for any interpretation of the effects of low-LET radiations of different quality upon many physical and biological detectors. Recent work has demonstrated that nuclear emulsions can be processed so as to achieve blackness which varies as the exposure to a power ranging from 1 to 4 (Larsson, Pinkerton, and Katz 1977), and optionally can have an initial linear response combined with subsequent supralinearity (Larsson, Roth, and Katz 1975). Such characteristics are not unlike those of biological cells. It is of further interest that the grains of these emulsions are relatively homogeneous, as shown in Figures 2 and 3 (R. H. Taber, private communication) and have a mean diameter of $0.21 \mu \mathrm{m}$ (or an effective diameter of $1.3 \mu \mathrm{m}$ ), in the range of sensitive element sizes attributed to biological cells. As a consequence we have initiated studies of the shape variations of the blackness-exposure curves of supralinear emulsions exposed to lowLET radiations.

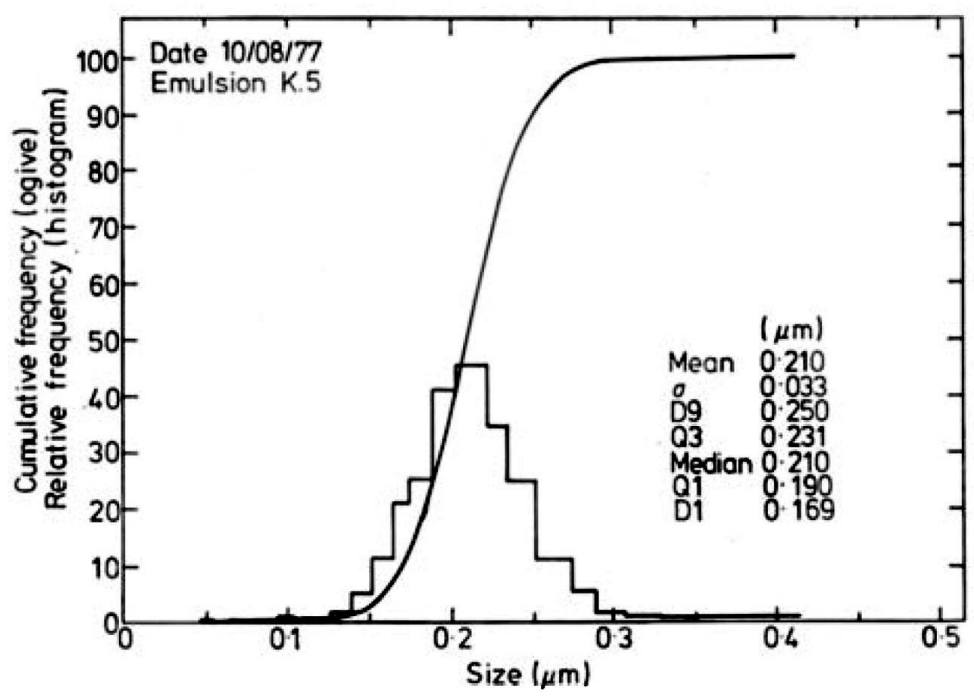

Figure 3. Crystal size distribution for Ilford K.5 emulsion grains. (R. H. Taber, private communication.) 


\section{Experimental details}

In this study we have used three types of Ilford nuclear emulsions of the K series: K.5, K.0, and K-2.5, all fabricated from a stock K.0 emulsion to which inorganic sensitizers or desensitizers are added. The emulsion was coated onto 2.54 $\mathrm{cm} \times 7.62 \mathrm{~cm}$ glass plates to a thickness of $10 \mu \mathrm{m}$. Plates were exposed to X-rays from 15 to $160 \mathrm{kV}_{\mathrm{p}^{\prime}}$ from a Torrex-150 X-ray unit having a tungsten target tube with an $0.4 \mathrm{~mm}$ thick Be window. Each plate was exposed for 13 different exposure times in places about $4 \mathrm{~mm}$ in diameter, so that a single sensitometric curve was obtained with a single plate. Blackness was measured with a Macbeth TD504 digital reading transmission densitometer that rounded to 0.01 density units. In the present work, we emphasize relative exposure. However, to gain an approximate relationship between emulsion exposures and those for biological cells, exposures were measured with a Victoreen condenser R-meter, model 570, used with model 651-250 R low energy ion chamber, and with model 70-5 $25 \mathrm{R}$ medium energy ion chamber.

Plates were developed in a solution of $p$-aminophenol hydrochloride, to which two buffering solutions were added in different concentrations to achieve different developer activity (Stevens 1951, Larsson et al. 1977). An anti-foggant, benzotriazole (Kodak Antifog No. 1), was added as required to achieve control of the initial low exposure linear portion of the blackness-exposure curve. Plates were presoaked in distilled water for $10 \mathrm{~min}$ at $20^{\circ} \mathrm{C}$, and were then developed (4 plates at one time) in $300 \mathrm{ml}$ of solution, with the ratio of surface area of emulsion to developer volume held constant. Processing was at $20^{\circ} \mathrm{C}$. After development the plates were immersed in a $4 \%$ acetic acid stop solution for $1 \mathrm{~min}$. After a $10 \mathrm{~min}$ wash in distilled water, the plates were fixed for $5 \mathrm{~min}$, followed by dilution of the fix with water, in two steps. The plates were then washed, and finally dried in methanol for $15 \mathrm{~min}$, and then in air overnight at room temperature. No agitation was used in the development step.

\section{Results}

Blackness-exposure curves for three different nuclear emulsions, developed so as to display increasing supralinearity, are shown in Figure 4. Except at the lowest exposure, where both background and densitometer rounding to the nearest 0.01 density unit introduce fluctuations in the results, there is no consistent difference in the shapes of the curves with a change in the voltage applied to the X-ray tube, or with the degree of filtration, as shown in the figure. Here the lines drawn to accompany the plotted points are from fitted mixtures of members of the cumulative Poisson distribution given by the equation $P(c, A)=1-\mathrm{e}^{-A} \sum_{x=0}^{c-1}$ $A^{x} / x !$, in which $c$ is the hittedness, and the average number of hits per target $A=0$ (exposure $/ a) / E_{0}$, with values of the normalizing parameter $a$ and of $E_{0}$ shown in the caption.

The data for K.5 emulsion are replotted in Figure 5, where they are superimposed on data for V79 Late S Chinese hamster cells exposed to gamma rays (Hall 1975). Two scales are used. The top and right scales are for the biological data, while the bottom and left scales are for the emulsion. One may consider here that both sets of data are well fitted by the $\alpha-\beta$ model, with appropriately different values of the parameters. Though the emulsion data extend to substantially lower "dose" and survival levels than the cellular data, there is no change in curve shape with radiation quality. 


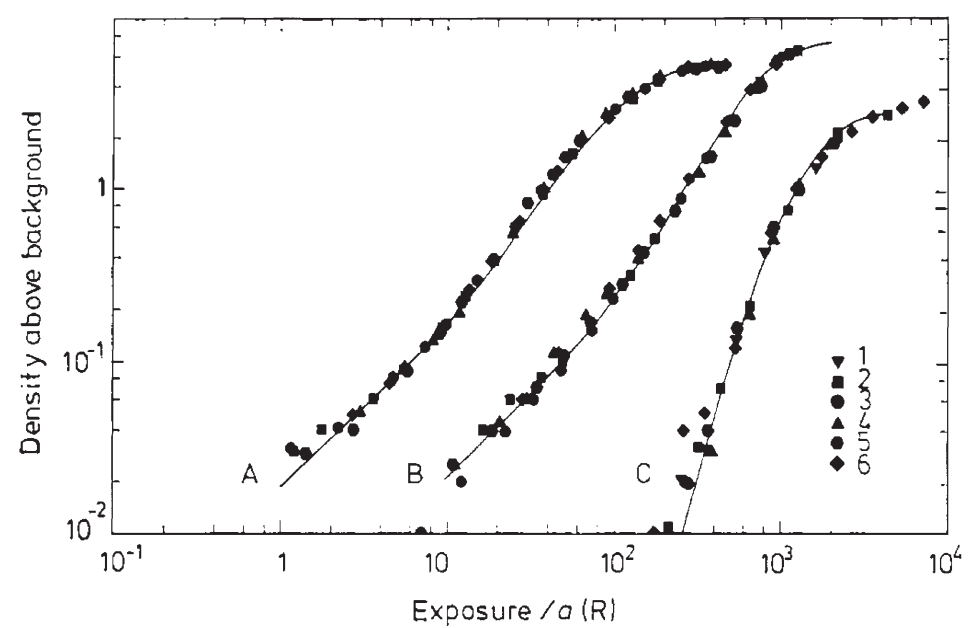

Figure 4. Blackness-exposure curves for nuclear emulsions of the Ilford $\mathrm{K}$ series, developed to supralinearity. Curves have the same shape for X-rays of different energies, from 15 to $150 \mathrm{kV}_{\mathrm{p}}$. The plotted curves are fitted from mixtures of $P(c, A)$ functions from the cumulative Poisson distribution, where $A=($ exposure $/ a) / E_{0}$ given below. The normalizing constant $a$, for superposition of the blackness-relative exposure curves, is given in the table below.

Data for curves:

\begin{tabular}{|c|c|c|c|c|c|c|}
\hline \multirow[b]{2}{*}{ Curve } & \multirow[b]{2}{*}{ Emulsion } & \multirow{2}{*}{$\begin{array}{l}\text { Developer } \\
\text { Stevens No. }\end{array}$} & \multirow{2}{*}{$\begin{array}{l}\text { Time } \\
(\mathrm{min})\end{array}$} & \multicolumn{3}{|c|}{ Parameters } \\
\hline & & & & $E_{0}(\mathrm{R})$ & $c$ & $(\%)$ \\
\hline \multirow[t]{2}{*}{ A } & K.5 & 7 & 160 & 56 & 1 & $\overline{2}$ \\
\hline & & & & 560 & 2 & 98 \\
\hline \multirow[t]{2}{*}{ B } & K.0 & 0.5 & 40 & 245 & 1 & 7 \\
\hline & & $\begin{array}{c}\left(+0.67 \mathrm{~g}^{-1}\right. \\
\text { of antifog) }\end{array}$ & & 245 & 3 & 93 \\
\hline C & $\mathrm{K}-2.5$ & 8 & 40 & 4000 & 4 & 100 \\
\hline
\end{tabular}

Data for symbols:

\begin{tabular}{cccccc} 
& & & \multicolumn{3}{c}{ Values of $a$} \\
\cline { 4 - 6 } Symbol & $\begin{array}{c}\text { X-rays } \\
\left(\mathrm{kV}_{\mathrm{p}}\right)\end{array}$ & $\begin{array}{c}\text { HVL } \\
(\mathrm{mm} \text { of Al })\end{array}$ & $\mathrm{A}$ & $\mathrm{B}$ & $\mathrm{C}$ \\
\hline 1 & 15 & 0.040 & - & - & 10 \\
2 & 30 & 0.050 & 12 & 1 & $\dagger$ \\
3 & 50 & 0.055 & 12 & 1.2 & - \\
4 & 100 & 0.065 & 10 & 1 & 11 \\
5 & 150 & 0.065 & 10 & 0.8 & 11 \\
6 & $100 \ddagger$ & 3.2 & 1.6 & 0.15 & 1.7
\end{tabular}

† Dosimetry not available.

$\ddagger 2 \mathrm{~mm}$ Al filter. 


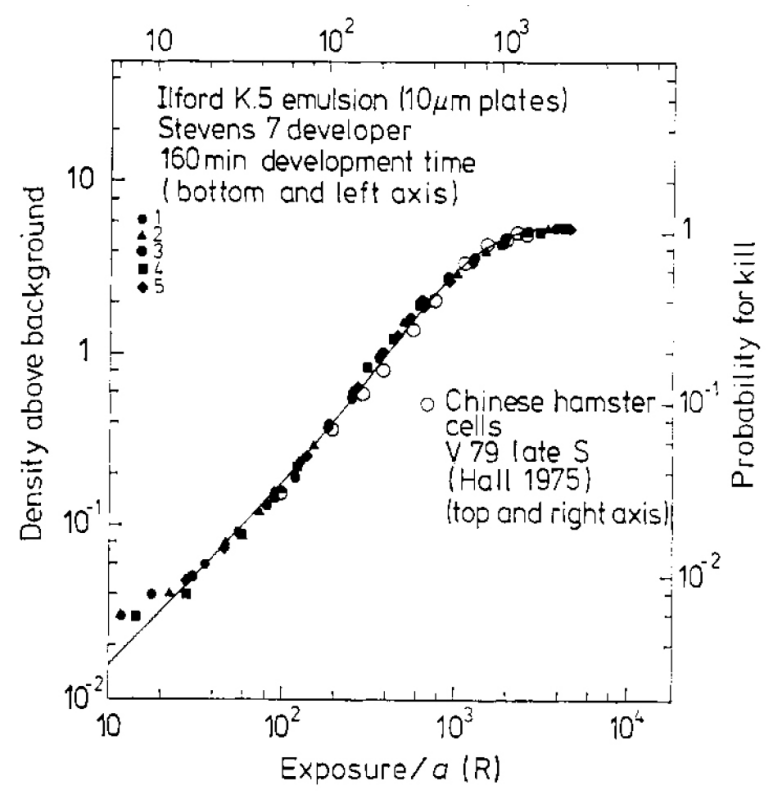

Figure 5. Curve A of Figure 4 is replotted to show that its shape is close to that of the probability for cell killing relative to absorbed dose found for V79 Late S Chinese hamster cells, by Hall (1975). The line is fitted to the biological data by Hall, using the $\alpha-\beta$ model, with the following parameters:

$$
\begin{array}{ll}
{ }^{60} \text { Co gamma rays. } & P=1-\exp \left[-\left(\alpha D+\beta D^{2}\right)\right] \\
& \alpha=5.3 \times 10^{-4} \mathrm{rad}^{-1} \\
& B=1.9 \times 10^{-6} \mathrm{rad}^{-2}
\end{array}
$$

Data for symbols:

\begin{tabular}{cccc}
\hline Symbol & $\begin{array}{c}\text { X-rays } \\
(\mathrm{kVp})\end{array}$ & $\begin{array}{c}\text { HVL } \\
(\mathrm{mm} \text { of } \mathrm{Al})\end{array}$ & $\begin{array}{c}\text { Exposure } \\
\text { factor, } a\end{array}$ \\
\hline 1 & 30 & 0.050 & 1.2 \\
2 & 50 & 0.055 & 1.2 \\
3 & 100 & 0.065 & 1.0 \\
4 & 150 & 0.065 & 1.0 \\
5 & $100 \dagger$ & 3.2 & 0.16 \\
\hline
\end{tabular}

† $2 \mathrm{~mm} \mathrm{Al} \mathrm{filter.}$

Yet another result of interest to radiobiology is the extent to which fading of the latent image leads to curves which mimic Elkind recovery. In Figure 6 we show the result of fractionated exposure of emulsions. An emulsion plate is exposed to $780 \mathrm{R}$ of $100 \mathrm{kV}_{\mathrm{p}} \mathrm{X}$-rays, and then is stored for $16 \mathrm{~h}$ at $100 \%$ humidity at room temperature. It is then stored at low humidity for $2-3 \mathrm{~h}$ at $5^{\circ} \mathrm{C}$, for drying, and then exposed to a series of sensitometric exposures. Immediately afterwards a second plate is exposed over a range of sensitometric exposures. Both are then developed in the same baths of processing solutions. To emphasize the point an appropriate figure is taken from Elkind and Whitmore (1967), and shown as Figure 7.

It would appear that one might be able to use emulsions to test physical aspects of models for radiobiological processes. 


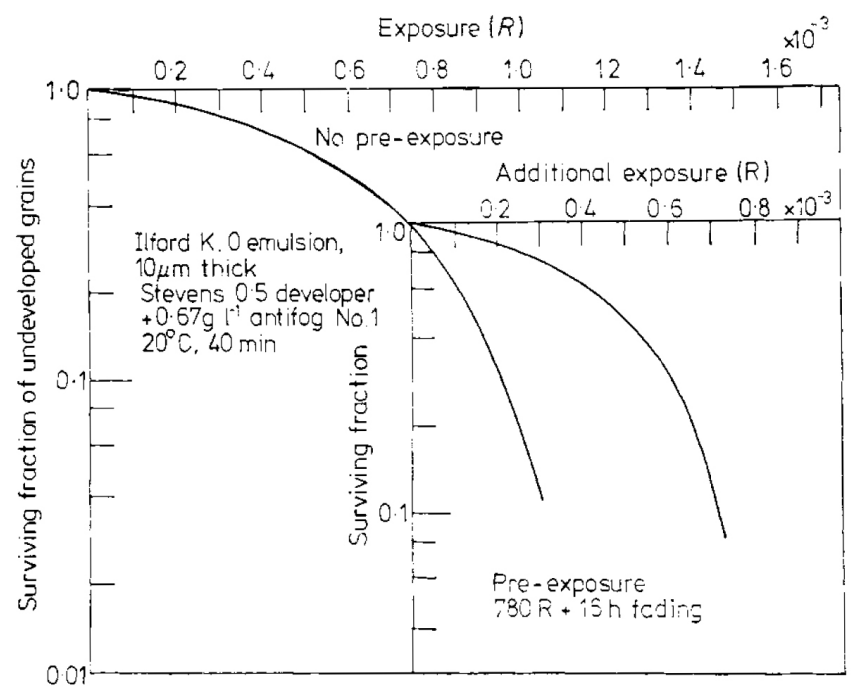

Figure 6. To be compared with Figure 7. Fading of the latent image in K.0 emulsion mimics Elkind recovery in biological cells in fractionated exposures. An emulsion plate is exposed to $580 \mathrm{R}$ of $100 \mathrm{kV}_{\mathrm{p}} \mathrm{X}$-rays, stored for $16 \mathrm{~h}$ in a humidity chamber at room temperature, to accelerate fading, and is then stored for $2-3 \mathrm{~h}$ at $5{ }^{\circ} \mathrm{C}$ for drying. A second set of sensitometric exposures is made over the exposed plate. Immediately afterwards a second plate is exposed to a set of sensitometric exposures. Both plates are developed at the same time in the same processing solutions.

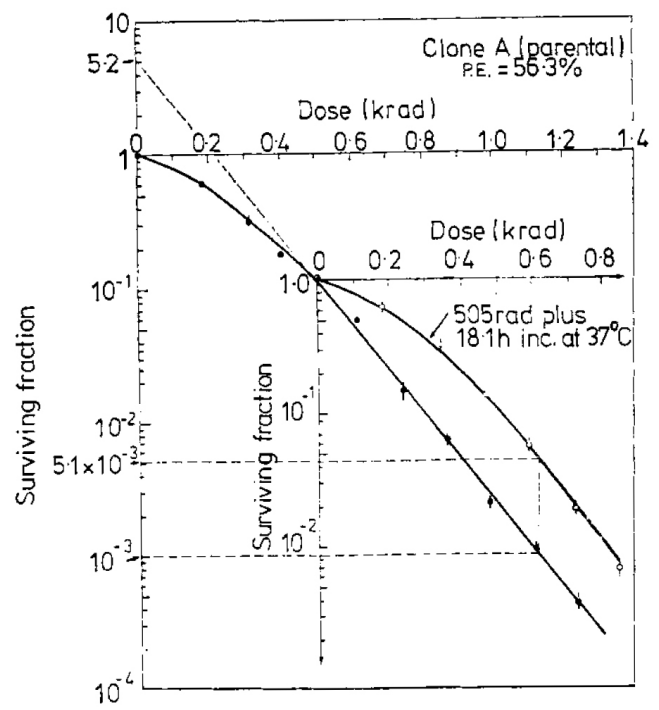

Figure 7. Elkind recovery of hamster cells in fractionated exposures. (Elkind and Whitmore 1967.)

\section{Discussion}

Given a biological dose-response relation, it appears that one may be able to process nuclear emulsions to match the shape of that response curve. We do not know whether the two curves can be superimposed at the same exposure level. As yet we have no experience with high-LET radiations and so cannot say 
whether an emulsion which matches a biological response with low-LET radiations will also match that response with high-LET radiations. There are important differences between these two systems, especially in that there is no structure analogous to a cell nucleus in the photographic grain. The response of emulsions should be described by three parameters, the hittedness $c$, the characteristic dose $E_{0}$, and the radius of the grain $a_{0}$, rather than the four needed for biological cells, the additional parameter describing the size of the nucleus.

As for the question raised by Dudley, as to why there is not a larger component of 1-hit grains for lower voltage X-rays, we can only suggest that the low energy end of the electron slowing down spectrum plays a dominant role in the photographic process, as we believe it does for biological cells. At the low energy end, where ionization cross-sections peak, the slowing down spectrum has largely forgotten the initial energy spectrum of the primary radiation. Both from Dudley's work and our own, there is no change in the relative photographic effectiveness of low-LET radiations of different quality, at any dose level, and for any blackness-exposure curve yet achieved. We are not able to resolve the difference between these photographic results and a contradictory biological finding (Bond, Meinhold, and Rossi 1978) that dose-response curves for different lowLET radiations are of such different shape that the RBE may climb to 4 at low doses, in comparing orthovoltage $\mathrm{X}$-rays to gamma rays.

In addition to their potential as modeling systems to test physical aspects of theories of the interaction of ionizing radiations with biological systems, these supralinear emulsion-processing combinations are likely to have important practical applications, for they represent the first opportunity to tailor the response of a physical detector to match a biological system. Aside from obvious limitations from the photoelectric effect, we can imagine that from them we can make a true REM dosimeter. Figure 5 indicates that this may soon be true for electron irradiations. Work is now in progress to find the extent to which emulsion response matches cellular response to high-LET radiations as well.

\section{Acknowledgment}

This work was supported by the Department of Energy, the National Science Foundation (RANN) and the International Atomic Energy Agency.

\section{References}

Barkas, W. H. 1963 Nuclear Research Emulsions (New York: Academic)

Bond, V. P., Meinhold C. B., and Rossi H. H. 1978 Health Phys. 34: 433

Dudley, R. A. 1951 Ph.D. Thesis, Massachusetts Institute of Technology

Elkind, M. H., and Whitmore G. F. 1967 The Radiobiology of Cultured Mammalian Cells (New York: Gordon and Breach)

Erickson, L., and Splettstosser, H. R. 1977 The Theory of the Photographic Process, ed. T. H. James (New York: Macmillan) 4th edn.

Farnell, G. C., and Chanter J. B. 1961 J. Photogr. Sci. 9: 79

Glocker, R. 1960 Z. für Physik 160: 568

Golden, R., and Tochilin E. 1959 Health Phys. 2: 199

Greening, J. R. 1951 Proc. Phys. Soc. B 64: 977

Hall, E. J. 1975 Cell Survival after Low Doses of Radiation, ed. T. Alper (Chichester: Wiley and Bristol: Institute of Physics)

Larsson, L., Pinkerton, F. E., and Katz, R. 1977 Nuclear Track Detection vol. 1, p. 49 
Larsson, L., Roth, R. A., and Katz, R. 1978 Proc. Third Symp. on Neutron Dosimetry in Biology and Medicine (Luxembourg: CEC) p. 659

Mitchell, J. W. 1978 Photogr. Sci. Eng. 22: 1

Stevens, G. W. W. 1951 Photographic Sensitivity, ed. J. W. Mitchell (London: Butterworth)

Valentine, R. 1966 Advances in Optical and Electron Microscopy vol. 1, p. 180

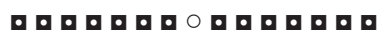

\section{Résumé:}

Aspects radiobiologiques d'émulsions photographiques supralinéaires

Des émulsions nucléaires de la série Ilford $\mathrm{K}$, exposées à des rayons $\mathrm{X}$ de 15 à $150 \mathrm{kV}_{\mathrm{p}}$ et systématiquement sous-développées, manifestant des courbes supralinéaires de noirceur en fonction de l'exposition, allant de 1 à 4 cibles et dont la forme est la même à toutes les tensions d'excitation. Le processus peut être ajusté de manière à ce que la forme de la courbe soit bien représentée par le modèle $\alpha-\beta$ et correspond à une courbe expérimentale dose contre réponse obtenue au moyen de cellules de hamster après irradiation aux rayons gamma. La granulométrie effective de ces émulsions est de 1,3 $\mu \mathrm{m}$, lorsqu'elle est normalisée pour le matériel de densité unitaire, afin d'être comparée aux éléments de cellules biologiques sensibles aux radiations. Avec des expositions fractionnées, l'on produit des courbes de réponse à récupération mimique Elkind.

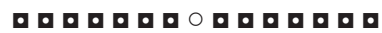

\section{Zusammenfassung:}

Radiobiologische Aspekte supralinearer lichtempfhdlicher Schichten

Nukleare Schichten der Ilford-K-Serie, die Röntgenstrahlen von 15 bis $150 \mathrm{kV}_{\mathrm{p}}$ ausgesetzt und systematisch unterentwickelt werden, zeigen supralineare Schwärzekurven, die über Belichtung aufgetragen werden. Diese werden durch 1 bis 4-hit gekennzeichnet, und ihre Form bleibt bei allen Erregerspannungen unverändert. Der Prozess kann so abgestimmt werden, dass die Kurvenform durch das $\alpha-\beta$-Modell gut dargestellt wird und einer experimentellen Dosis/Reaktions-Kurve entspricht, die mit Hamsterzellen nach Bestrahlen mit Gamma-Strahlen erzielt wurde. Die effektive Korngrösse dieser Schichten beträgt 1,3 $\mu \mathrm{m}$ nach Normalisierung für Einheitsdichte-material zum Vergleich mit den strahlungsempfindlichen Elementen der biologischen Zellen. Bei fraktionierten Belichtungen werden Reaktionskurven erzeugt, die eine Elkind-Restitution nachahmen. 